\title{
Air Monitoring Network at Tonopah Test Range: Network Description, Capabilities, and Analytical Results
}

\author{
prepared by \\ William T. Hartwell, Jeffrey Daniels, George Nikolich, Craig Shadel, \\ Ken Giles, Lynn Karr, Tammy Kluesner
}

submitted to

U.S. Department of Energy

National Nuclear Security Administration

Nevada Site Office

January 2012

Publication No. 45243 
Reference herein to any specific commercial product, process, or service by trade name, trademark, manufacturer, or otherwise, does not necessarily constitute or imply its endorsement, recommendation, or favoring by the United States Government or any agency thereof or its contractors or subcontractors.

Available for sale to the public from:

U.S. Department of Commerce

National Technical Information Service

5301 Shawnee Road

Alexandria, VA 22312

Phone: 800.553.6847

Fax: 703.605.6900

Email: orders@ntis.gov

Online ordering: http://www.osti.gov/ordering.htm

Available electronically at http://www.osti.gov/bridge

Available for a processing fee to the U.S. Department of Energy and its contractors, in paper, from:

U.S. Department of Energy

Office of Scientific and Technical Information

P.O. Box 62

Oak Ridge, TN 37831-0062

Phone: 865.576.8401

Fax: 865.576.5728

Email: reports@adonis.osti.gov 


\title{
Air Monitoring Network at Tonopah Test Range: Network Description, Capabilities, and Analytical Results
}

\author{
prepared by \\ William T. Hartwell, Jeffrey Daniels, George Nikolich, Craig Shadel, \\ Ken Giles, Lynn Karr, Tammy Kluesner \\ Desert Research Institute \\ Nevada System of Higher Education
}

Publication No. 45243

submitted to

U.S. Department of Energy

National Nuclear Security Administration

Nevada Site Office

January 2012

\begin{abstract}
The work upon which this report is based was supported by the U.S. Department of Energy under Contract \#s DE-AC52-06NA26383 and DE-NA0000939. Approved for public release; further dissemination unlimited.
\end{abstract}


THIS PAGE INTENTIONALLY LEFT BLANK 


\section{CONTENTS}

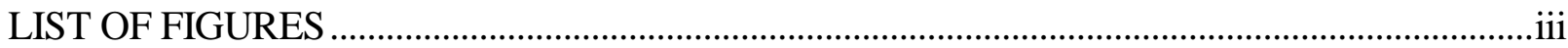

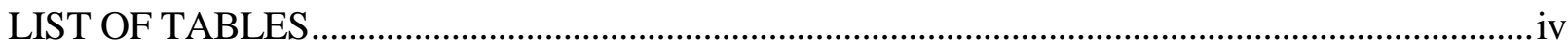

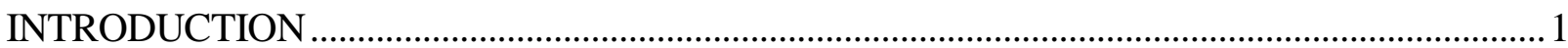

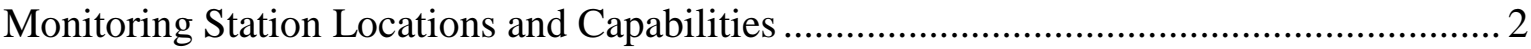

Station 400: Range Operations Center ................................................................ 2

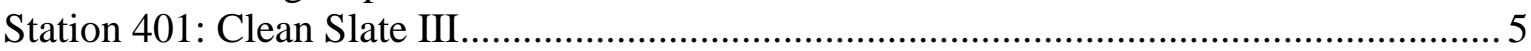

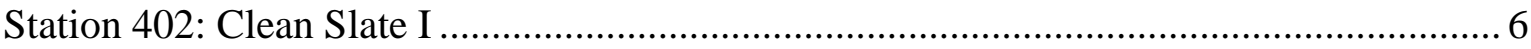

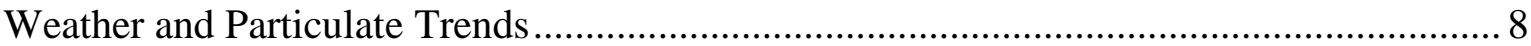

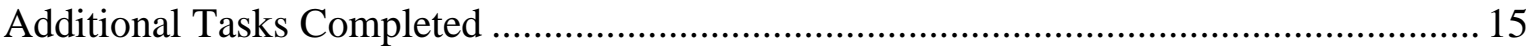

TTR Air Monitoring Network Database..................................................................... 17

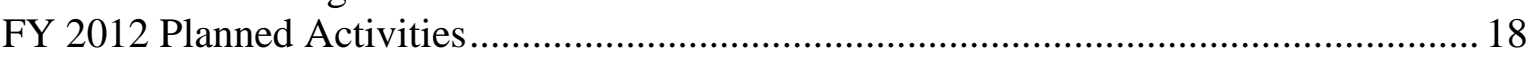

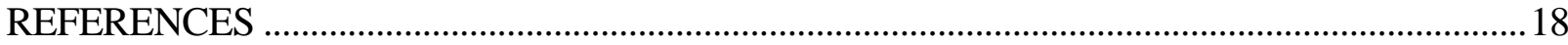

\section{LIST OF FIGURES}

1. Location of Monitoring Stations on TTR ................................................................. 3

2. Wind rose diagrams of average 10 and 15 minute wind speeds for the period June 2008 through November 2009 for Stations 400 and 401 on the TTR. ............................... 3

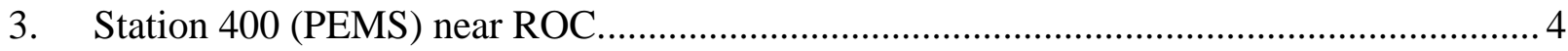

4. Station 401, solar powered air sampler. ..................................................................... 6

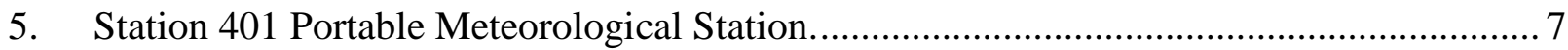

6. Station 402 solar powered air sampler and portable meteorological station...................... 7

7. Ambient air temperature for Station 400 for the period 1/1/2010 to 10/1/2011 ............... 8

8. Ambient air temperature for Station 401 for period 1/1/2010 to 10/1/2011 _..................... 9

9. Average air temperature for Stations 400 and 401 for the period 1/1/2010 to

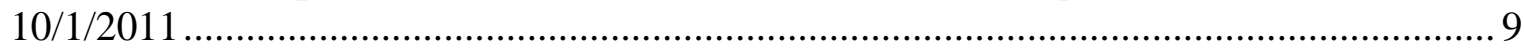

10. Precipitation events for Station 401 for the period 1/1/2010 to 10/1/2011 ..................... 10

11. Soil volumetric water content trend for Station 401 for the period 1/1/2010 to

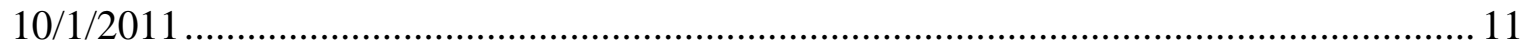

12. Wind roses for Station 400, 401, and 402 for period 1/1/2010 to 10/1/2011_................. 12

13. Wind speed histogram for Station 400 for the period 1/1/2010 to 10/1/2011 ................... 14

14. Wind speed histogram for Station 401 for the period $1 / 1 / 2010$ to $10 / 1 / 2011 \ldots \ldots \ldots \ldots \ldots . . . . .14$

15. Wind speed and PM10 trends for Station 400 for the period 1/1/2010 to 10/1/2011 ........ 16

16. Wind speed and PM10 trend for Station 401 for the period 1/1/2010 to 10/1/2011 _........ 16

17. Sample high wind and high PM10 event for Station 401 from April, 2011 ................... 17 


\section{LIST OF TABLES}

1. Wind and PM10 data summary for Station 400 for the period 1/1/2010 to $10 / 1 / 2011$

2. Wind and PM10 data summary for Station 401 for the period 1/1/2010 to 10/1/2011

\section{LIST OF ACRONYMS}

CAU

CEMP

CS III

DOE

GOES

PEMS

PIC

ROC

RSL

SNL

SPAS-MT

TTR

NNSA/NSO

NTTR

WRCC
Corrective Action Unit

Community Environmental Monitoring Program

Clean Slate III

Department of Energy

Geostationary Operational Environmental Satellite

Portable Environmental Monitoring Station

Pressurized ion chamber

Range Operations Center

Radiological Services Laboratory

Sandia National Laboratories

Solar Powered Air Sampler and Meteorological Tower

Tonopah Test Range

National Nuclear Security Administration, Nevada Site Office

Nevada Test and Training Range

Western Regional Climate Center 


\section{INTRODUCTION}

During the period April to June 2008, at the behest of the Department of Energy (DOE), National Nuclear Security Administration, Nevada Site Office (NNSA/NSO); the Desert Research Institute (DRI) constructed and deployed two portable environmental monitoring stations at the Tonopah Test Range (TTR) as part of the Environmental Restoration Project Soils Activity. DRI has operated these stations since that time. A third station was deployed in the period May to September 2011. The TTR is located within the northwest corner of the Nevada Test and Training Range (NTTR), and covers an area of approximately $725.20 \mathrm{~km}^{2}\left(280 \mathrm{mi}^{2}\right)$. The primary objective of the monitoring stations is to evaluate whether and under what conditions there is wind transport of radiological contaminants from Soils Corrective Action Units (CAUs) associated with Operation Roller Coaster on TTR. Operation Roller Coaster was a series of tests, conducted in 1963, designed to examine the stability and dispersal of plutonium in storage and transportation accidents. These tests did not result in any nuclear explosive yield. However, the tests did result in the dispersal of plutonium and contamination of surface soils in the surrounding area.

Station 400 is located in the general vicinity of the Range Operations Center (ROC), station 401 is located on the northwest end of Clean Slate III (CS III), and station 402 is located on the northwest end of Clean Slate I (CS I). Station 400 measures potential radionuclide concentration at the closest location where there are regular site workers. Station 401 at CS III is located at the perimeter of the largest of the three TTR Soils CAUs. The CS III site covers an area of approximately $12 \mathrm{~km}^{2}$ (1200 hectares), and is estimated to contain areas with plutonium concentrations in soil at and above $200 \mathrm{pCi} / \mathrm{g}$. This station measures the radionuclide concentration at the boundary of the site in one of the predominant downwind directions. Station 402, located at the perimeter of CS I, also measures the radionuclide concentration at the boundary of the site in the predominant downwind direction, as well as the saltation of ground particles in the vicinity.

The fundamental design of these stations is similar to that used in the Community Environmental Monitoring Program (CEMP). The TTR stations collect data on selected meteorological and environmental parameters (e.g., wind speed and direction, airborne particulate concentration as a function of particulate size, etc.). In addition, airborne particulate samplers are deployed at each location to collect particulate samples for radiological analyses. Data are provided to the Western Regional Climatic Center (WRCC) for management and incorporation in to a TTR-specific database. The stations at the ROC and at CS III have been in continuous operations since July 2008, and the station at CS I became fully functional in September, 2011. This letter report provides a general summary of monitoring activities and station upgrades for the period October 2010 through September 2011. 


\section{Monitoring Station Locations and Capabilities}

As part of its work under the Soils Activity, DRI operates three portable monitoring stations at TTR. The Station 400 Portable Environmental Monitoring Station (PEMS) is located south of the ROC at: $37^{\circ} 45^{\prime} 25^{\prime}$ ' N, $116^{\circ} 45^{\prime} 26^{\prime}$ ' W (Figure 1). This station provides data where there is the greatest concentration of personnel associated with Sandia National Laboratories (SNL), which manages TTR for the DOE NNSA. In addition, Station 400 was located where line power was available to operate the instruments. The second, Station 401, Solar Powered Air Sampler and Meteorological Tower (SPAS-MT), consists of two components: 1) the air sampler located at $37^{\circ} 45^{\prime} 39^{\prime \prime} \mathrm{N}, 116^{\circ} 40^{\prime} 58^{\prime \prime} \mathrm{W}$ and 2 ) the auxiliary meteorological tower at $37^{\circ} 45^{\prime} 41^{\prime} \mathrm{N}, 116^{\circ} 40^{\prime} 59^{\prime}$ 'W. No line power is available at this site. These components are located along the fenced perimeter of the north end of CS III (Figure 1). The third station, Station 402, located at CS I, also consists of two components: an air sampler and an auxiliary meteorological tower located at $37^{\circ} 42.543^{\prime} \mathrm{N}, 116^{\circ} 39.444^{\prime}$ $\mathrm{W}$. These components are located along the fenced perimeter of the north end of CS I (Figure 1). The locations of Stations 401 and 402 were selected based on a review of wind speed and direction data collected at the Tonopah Airport (Engelbrecht et al., 2008) as well as for ease of access. Although these data were obtained from a period of limited time, they are continuous and less influenced by local topography than the CEMP station in Tonopah, Nevada. Data obtained for 2009 for stations 400 and 401 provided verification that their siting was appropriate (Figure 2).

All three stations are equipped with continuous low volume air samplers (flow rate approximately $0.05663 \mathrm{~m}^{3}\left[2 \mathrm{ft}^{3}\right.$ ] per minute) whose filters are collected, routinely, every two weeks. These filters are delivered to the Radiological Services Laboratory (RSL) at the University of Nevada, Las Vegas for analyses. Standard analyses include gross alpha/beta measurements and gamma spectral analysis. Samples may undergo alpha spectral analysis if initial gamma spectral analyses indicate the presence of Americium (Am)-241, which could suggest that plutonium particles are being transported.

\section{Station 400: Range Operations Center}

Station 400 is a portable station with all monitoring and sampling systems mounted on a 7' X 14' trailer (Figure 3). The station is located approximately $91.44 \mathrm{~m}$ (100 yd) southsouthwest of the ROC. Sensors include an anemometer, wind direction, pyranometer, tipping rain bucket, temperature/relative humidity probe, barometric pressure, soil temperature probe, pressurized ion chamber (PIC), and an ambient air particulate size profiler. Data from these sensors are collected and stored on a Campbell Scientific ${ }^{\mathrm{TM}}$, Logan, Utah CR1000 data logger. These data are then transmitted through a Geostationary Operational Environmental Satellite (GOES) transmitter to the WRCC. Regular quality assurance procedures include checking the PIC response and air volume throughput on the air sampler on a monthly basis. In addition to the real-time instruments, this station is equipped with two low volume air 


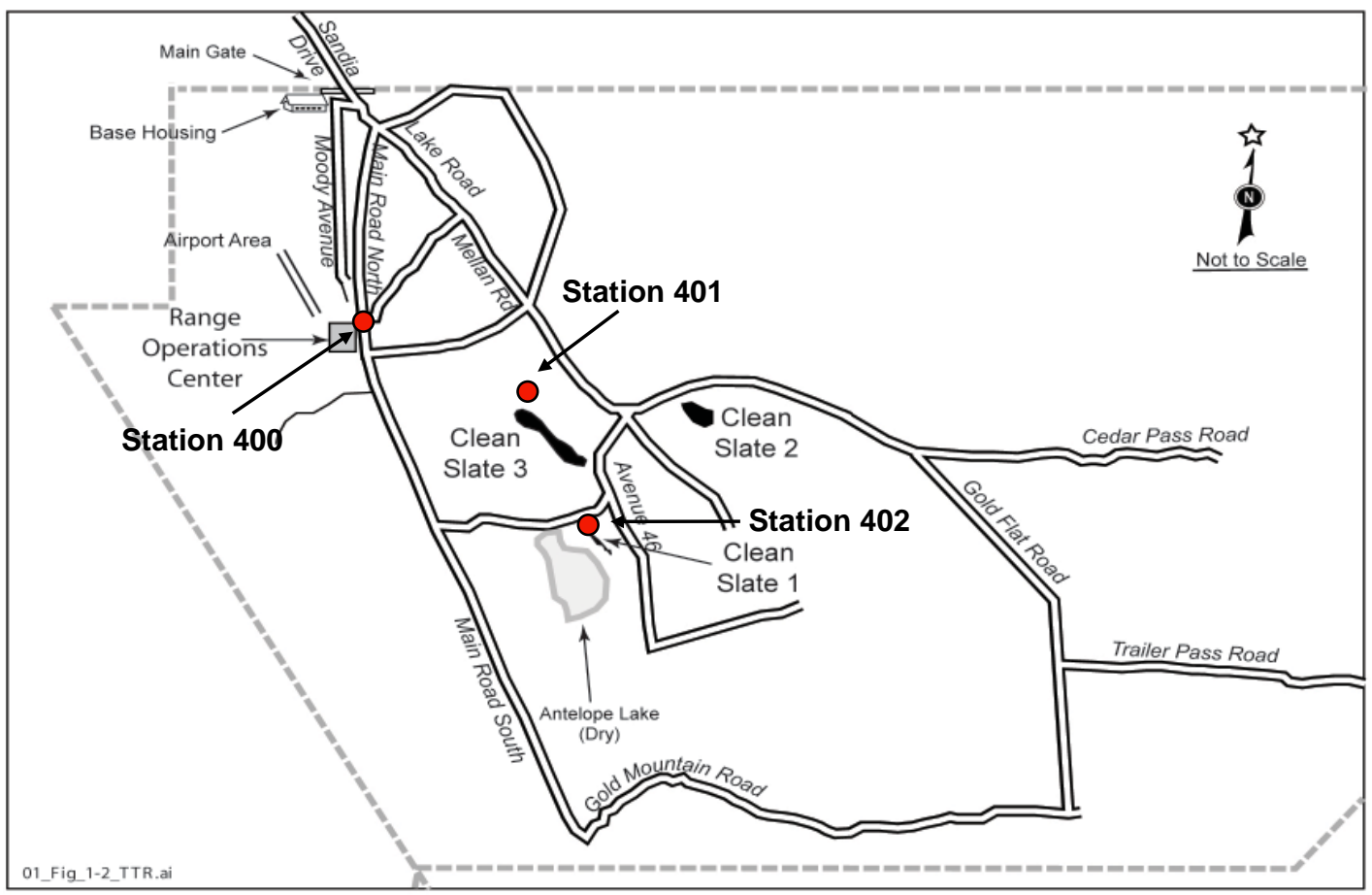

Abstracted from SAND2008 5070P, September 2008,

Figure 1. Location of Monitoring Stations on TTR.

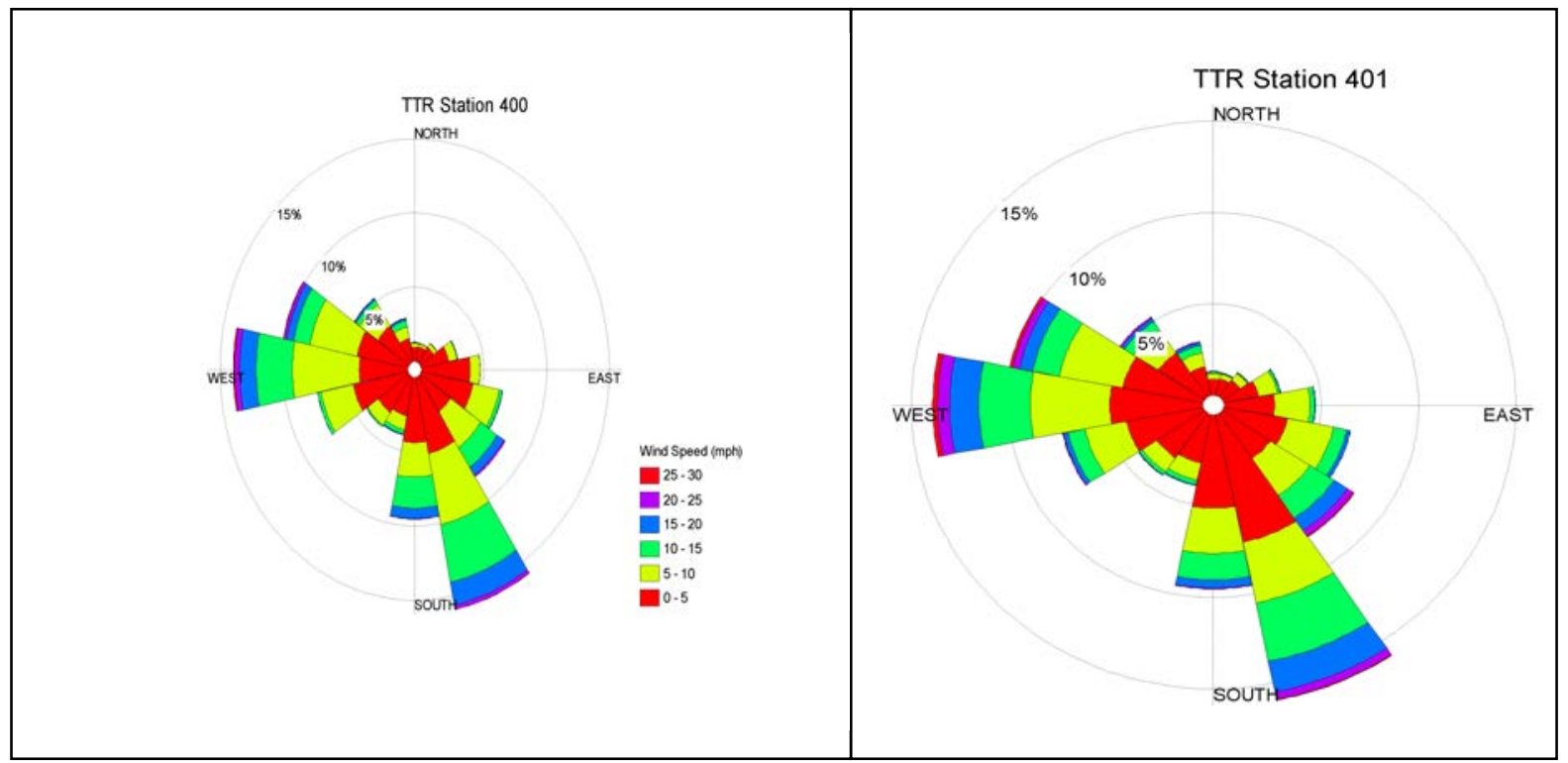

Figure 2. Wind rose diagrams of average 10 and 15 minute wind speeds for the period June 2008 through November 2009 for Stations 400 and 401 on the TTR. 


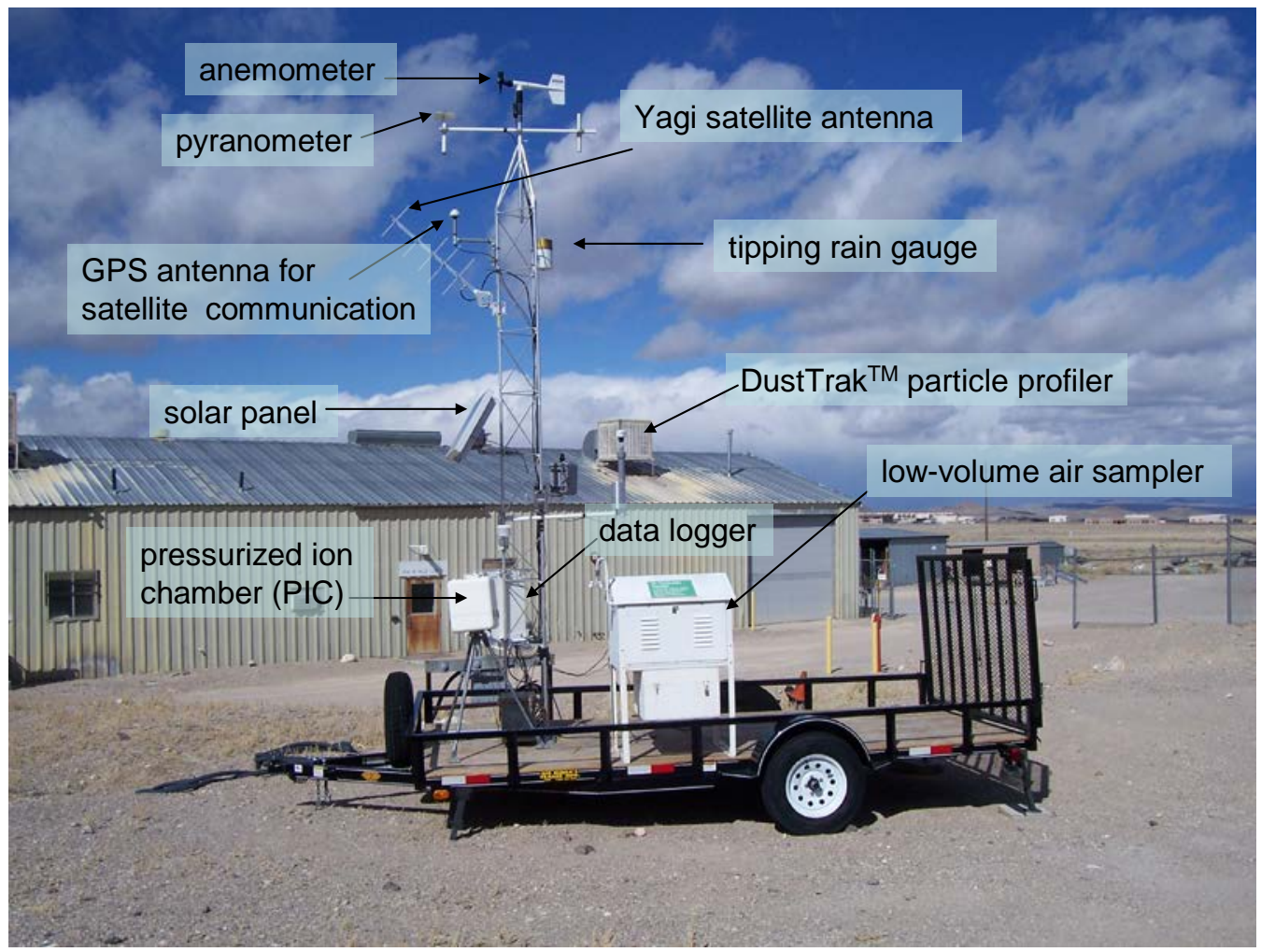

Figure 3. Station 400 (PEMS) near ROC.

samplers (AirMetrics, Eugene, Oregon MiniVols ${ }^{\mathrm{TM}}$ ) that can collect air samples on quartz Teflon filter media, which allows for different types of chemical and elemental analysis. These air samplers are intended to run in case of nearby wild fire or in conditions of extreme dust storms in which there may be value in distinguishing the relative contribution of organics and inorganic constituents. In addition, the station is equipped with an ambient air particulate size profiler (TSI, Shoreview, Minnesota, DustTrak $^{\mathrm{TM}}$ ). The DustTrak ${ }^{\mathrm{TM}}$ measures the concentration of suspended particulates in $\mathrm{mg} / \mathrm{m}^{3}$ in real time. Data can be used to determine whether high wind events are always associated with higher concentrations, and whether there are correlations between total particulate concentrations and radionuclide concentrations.

The station is also equipped with a continuous air particulate sampler from which 4 inch air filter samples are collected every two weeks and delivered to the laboratory every four to six weeks for analysis. Between January 2011 and December 2011, twenty-six air particulate filter samples have been collected. To date, 19 samples have been analyzed by gamma spectroscopy and for gross alpha/beta activity, with the remainder currently undergoing analysis. Except for the sampling period from 3/9/11 to 4/6/11 only naturally occurring radionuclides, predominantly Beryllium (Be)-7 and lead (Pb)-210, have been identified and measured. Samples collected during this time period showed the detection of 
Cesium (Cs)-134 and Cs-137 as well as elevated gross beta results. Their presence is a direct result of the release of airborne radionuclides during the Fukushima Nuclear Power Plant accident in Japan. Similar results were found in offsite samples from the DRI Community Environmental Monitoring Program. No other anthropogenic gamma emitting radionuclides such as Cobalt (Co)-60 or Americium (Am)-241 have been detected. Results of sampling analyses for CY 2010 were reported by Sandia National Laboratories (2011) and in part by Hartwell et al. (2010).

\section{Station 401: Clean Slate III}

Station 401 originally consisted of a solar powered air sampler (sampler and solar panels) mounted on a 7' X 14' trailer, plus a portable meteorological tower, with an anemometer, a temperature/relative humidity probe, and a DustTrak ${ }^{\mathrm{TM}}$. In FY2010, a pressurized ion chamber (PIC) and GOES satellite transmitter was also added to the station configuration. The addition of GOES transmission capabilities has enabled regular population of the online database for Station 401 by having data collected from the majority of instruments feed directly into it, eliminating the lag time caused by the necessity to manually download the data in the field during bi-weekly visits. The GOES transmissions also allow instrument operation to be monitored remotely at both stations. If data from an instrument appear spurious or are absent, personnel can be deployed to make repairs or change instruments quickly to minimize data loss.

Working with Hi-Q Products Inc., Alhambra, California, DRI constructed this mobile version of a solar powered air sampler based on a design currently being used by the U.S. Air Force on the NTTR. Internal airflow monitoring and self-adjustment capabilities allow the air sampler to maintain a near constant flow rate. An internal totalizer is used to collect and store airflow data. Data from the sensors are collected and stored on a Campbell Scientific ${ }^{\mathrm{TM}}$ data logger. Solar panels, with battery assist, provide power for the air sampler and the meteorological station. The configurations of the solar powered air sampler and the portable meteorological station are shown in Figures 4 and 5.

Air samples are collected every two weeks from Station 401 and delivered to the laboratory every four to six weeks for batch processing. Between January 2011 and December 2011, twenty-six air particulate filter samples were collected. To date, 19 samples have been analyzed by gamma spectroscopy and for gross alpha/beta activity. Except for the sampling period from 3/9/11 to 4/6/11, during which Cesium (Cs)-134 and Cs-137 as well as elevated gross beta results from the accident at Fukushima were detected, only naturally occurring radionuclides Be-7 and $\mathrm{Pb}-210$ have been measured on the samples. Analytical results for this time period are comparable to those observed at station 400 and are discussed in the previous section. Results of sampling analyses for CY 2010 were reported by Sandia National Laboratories (2011) and in part in Hartwell et al. (2010).

DRI installed a saltation monitoring station at Station 401 in August of 2011. This station will monitor sand and particle movement close to surface by aeolian transport. 
Saltation is a wind-driven process and is an important mechanism for transport and migration of material in desert environments. In conjunction with data collected from the meteorological stations, DRI will monitor for frequency of saltation events as a function of wind speed and wind direction in the immediate area. This instrument will help determine if there is significant material migration occurring from the site.

\section{Station 402: Clean Slate I}

In May 2011, DRI established Station 402, and installed a portable meteorological tower with an anemometer, a temperature/relative humidity probe, and a DustTrak ${ }^{\mathrm{TM}}$ as well as a GOES satellite transmitter. During August 2011, DRI installed a solar powered air sampler (sampler and solar panels) mounted on a trailer, and a pressurized ion chamber (PIC) was installed during September 2011. Collection of bi-weekly air samples from Station 402 began in August 2011, and were delivered to the laboratory every four to six weeks for batch processing. Between August 2011 and December 2011, a total of 9 samples were collected. All samples are currently undergoing gross alpha/beta and gamma spectroscopy analysis. Internal airflow monitoring and self-adjustment capabilities allow the air sampler to maintain a near constant flow rate. An internal totalizer is used to collect and store airflow data. Data from the sensors are collected and stored on a Campbell Scientific ${ }^{\mathrm{TM}}$ data logger. Solar panels, with battery assist, provide power for the air sampler and the meteorological station. The configurations of the solar powered air sampler and the portable meteorological station are shown in Figure 6. DRI installed a saltation monitoring station at Station 402 in August of 2011. This instrument will help determine if there is significant material migration occurring from the site.

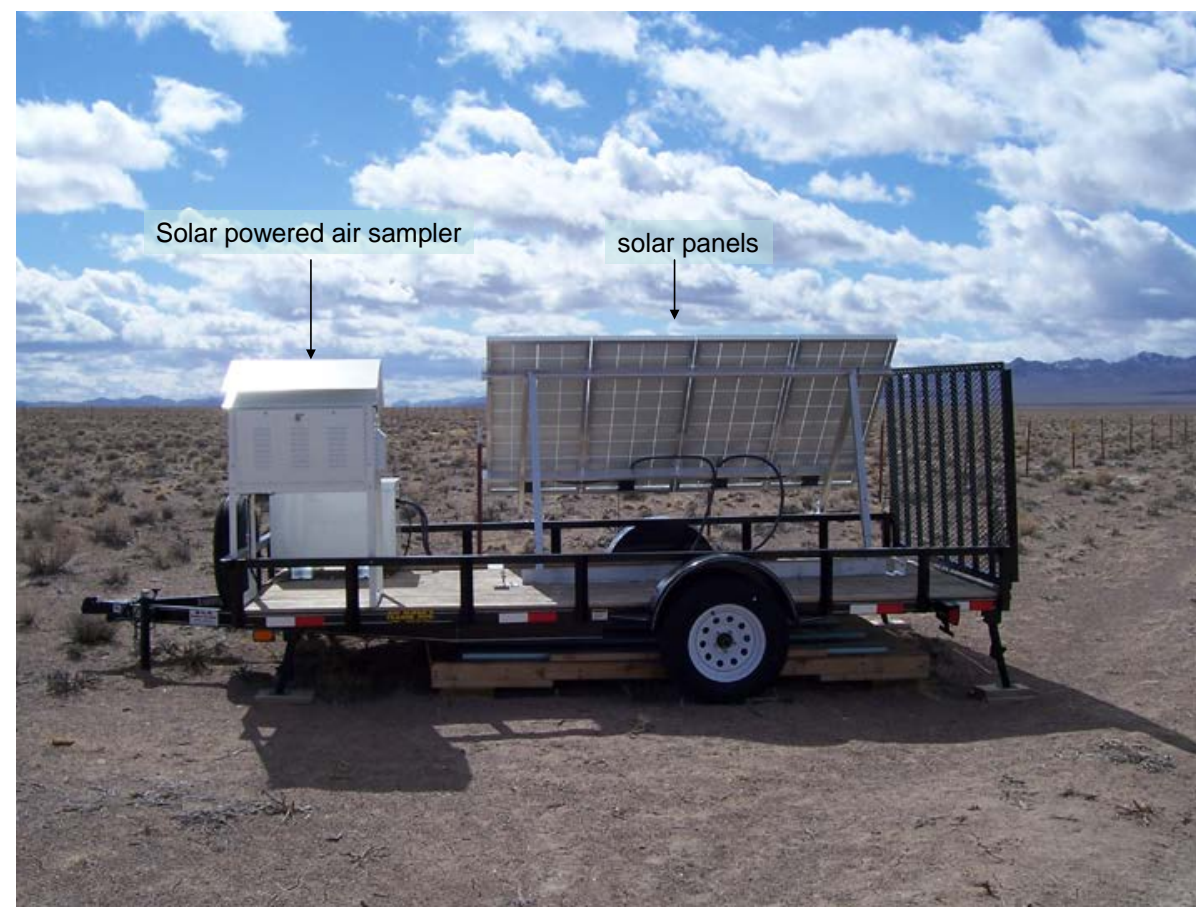

Figure 4. Station 401, solar powered air sampler. 


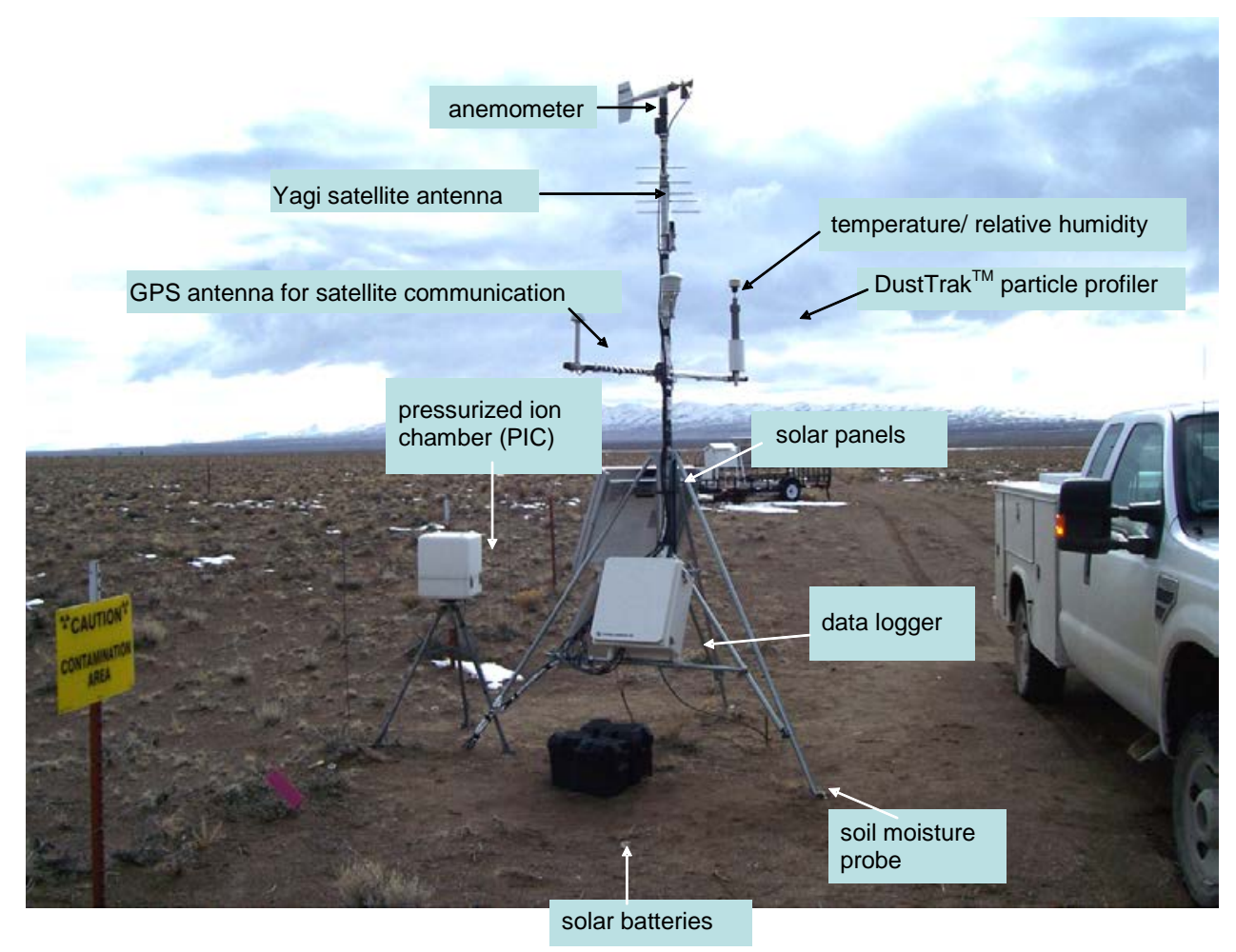

Figure 5. Station 401 Portable Meteorological Station.

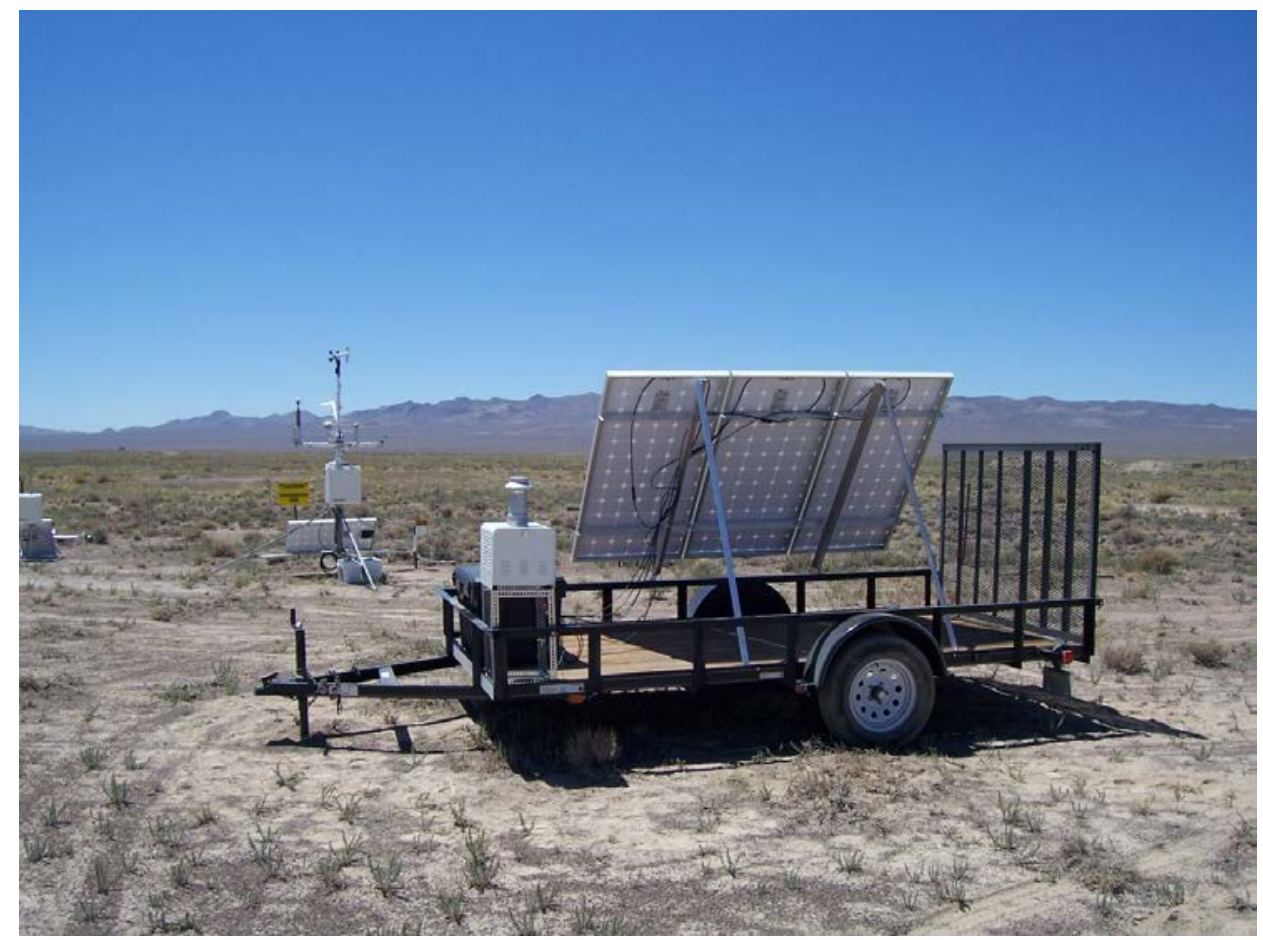

Figure 6. Station 402 solar powered air sampler and portable meteorological station. 


\section{Weather and Particulate Trends}

Temperature trends recorded at Station 400 and 401 between January, 12010 and October 1, 2011 are shown in Figures 7, 8 and 9. Three traces shown on Figures 7 and 8 indicate maximum, average, and minimum monthly temperature based on hourly average temperature. The trends between the two stations are very similar, as would be expected due to their close proximity. It is worth noting that the differences between the extremes (maximum and minimum temperatures) at Station 400 are lower due to Station 400 being surrounded by buildings and paved roads. This has the effect of a small urban heat island that averages out temperature extremes because of the increase in heat capacity and decrease in natural air circulation. Figure 9 shows that the average temperatures for two station are nearly identical which again is consistent with their close proximity. Maximum temperature during summer was between 90-100 degrees Fahrenheit and minimum temperature during winter was between -10 to 10 degrees Fahrenheit. During winter between November and February, temperatures below freezing keep the top layer of soil frozen and the frequency of high dust events goes down even though there are occurrences of high wind events (winds over $20 \mathrm{mph}$ ).

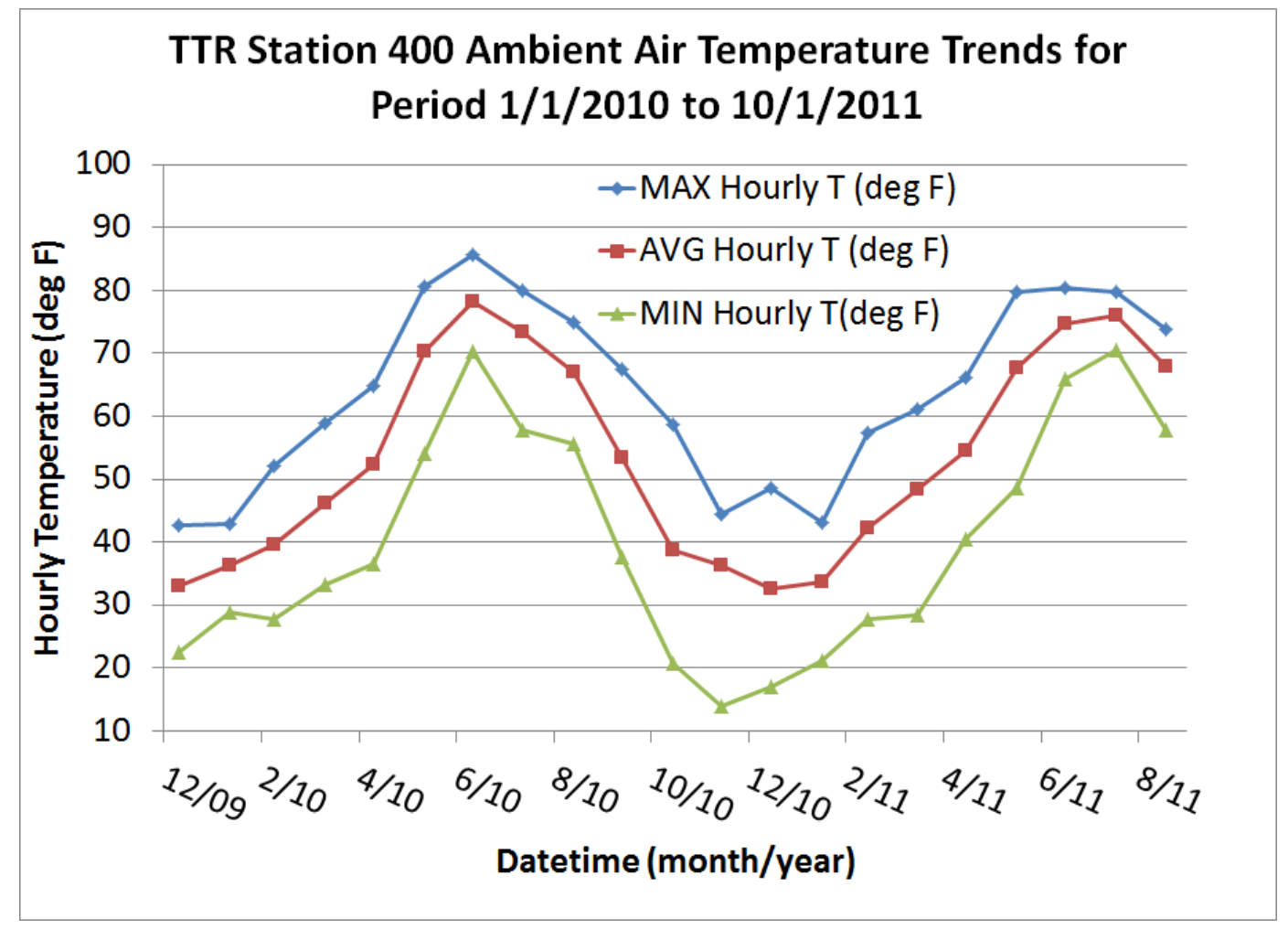

Figure 7. Ambient air temperature for Station 400 for the period 1/1/2010 to 10/1/2011. 


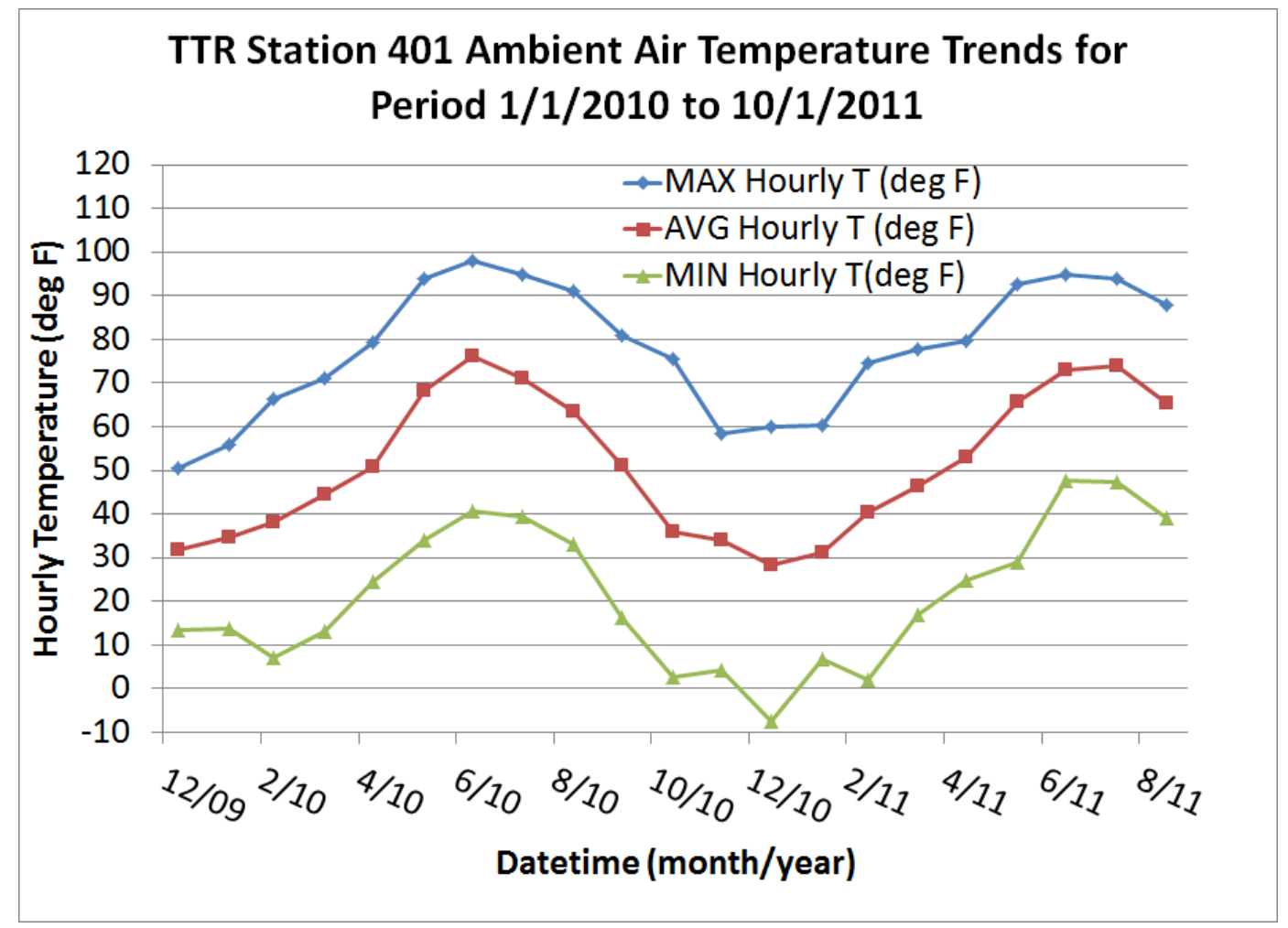

Figure 8. Ambient air temperature for Station 401 for period 1/1/2010 to 10/1/2011.

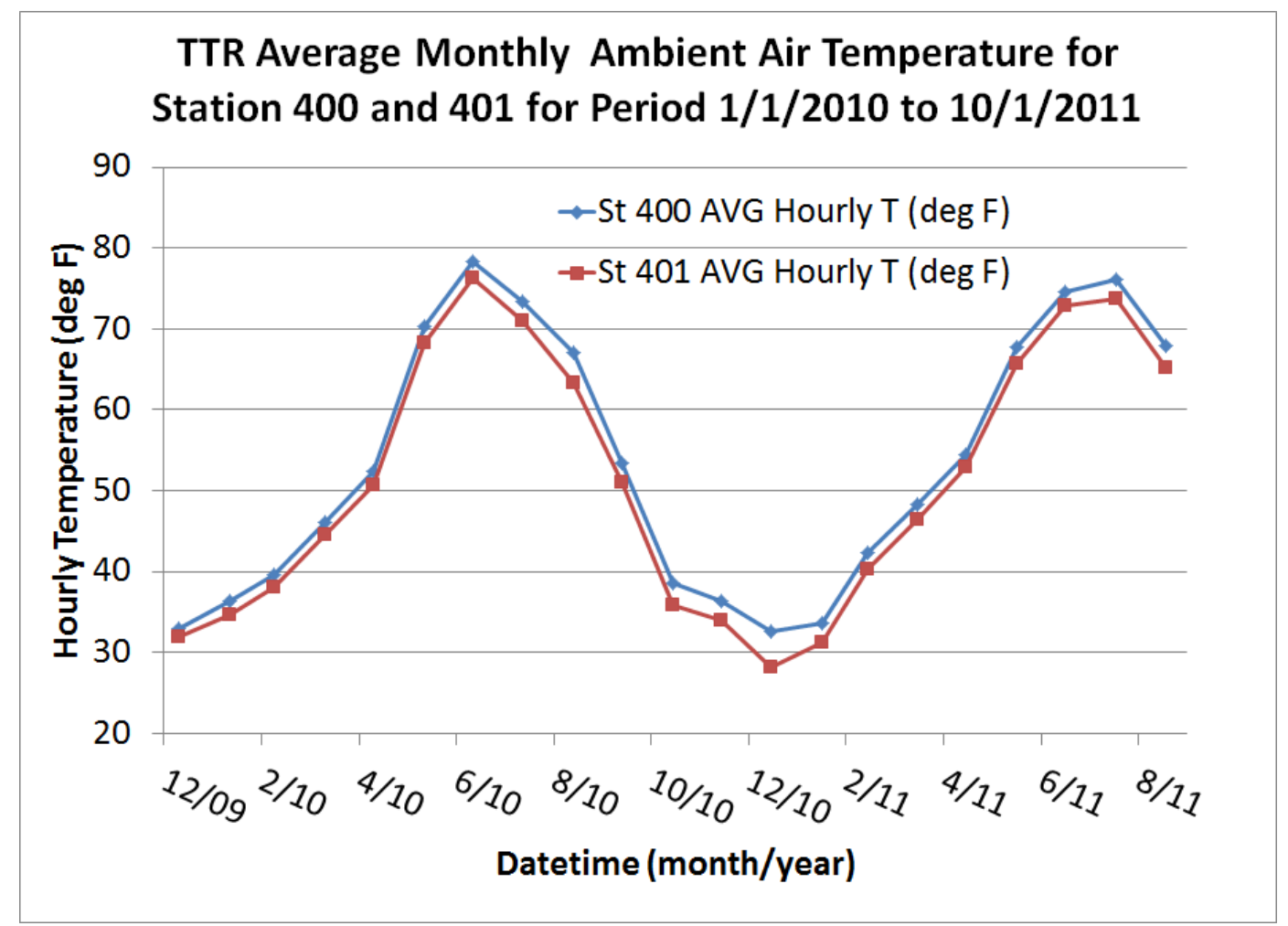

Figure 9. Average air temperature for Stations 400 and 401 for the period 1/1/2010 to 10/1/2011. 
The precipitation events and the total precipitation for Station 401 in the period between January, 12010 and October 1, 2011 are shown in Figure 10. The total precipitation for almost a two year period of 4.8 inches is equivalent to about 2.5 inches of rain fall per year. This average annual perception of about 2.5 inches recorded between 2010 and 2011 is below the historic annual average of about 4 inches or rain per year. It is important to note that precipitation events were recorded using a non-heated rain gauge which means that some snowfall may have been underestimated due to wind being able to remove the snow out of the rain gauge before it melted or sublimed. Soil volumetric water content was also monitored in the top two inches of soil using a TDR probe. The water content of this top layer of soil is most relevant to soil migration when soil was exposed to high winds. Figure 11 shows the volumetric water content of the top soil layer at Station 401. The increases in soil VWC (volumetric water content) coincided with the precipitation events and subsequent decreases of VWC correspond to drying periods and increases in air temperature during summer. The soil VWC is not a reliable indicator of soil stability because desert soils such at Station 401 are generally dry and capable of emitting dust whenever winds exceed saltation threshold. In some cases, intense but short rain events result in increased dust emissions because they disturb the soil crust and expose more fine soil particles to wind forces.

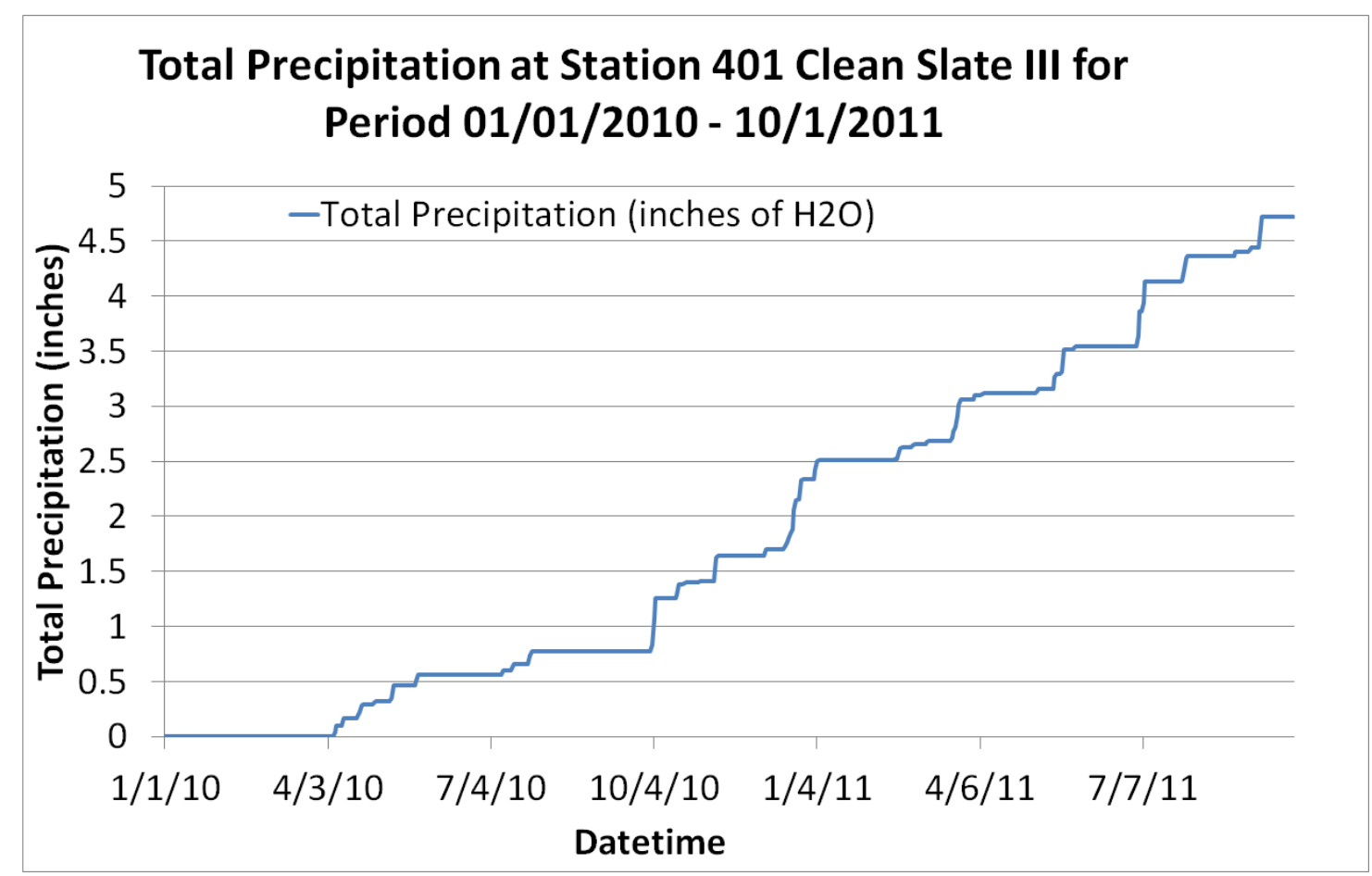

Figure 10. Precipitation events for Station 401 for the period 1/1/2010 to 10/1/2011. 


\section{Average Soil Volumetric Water Content at Station 401 Clean Slate III for Period 01/01/2010 - 10/1/2011}

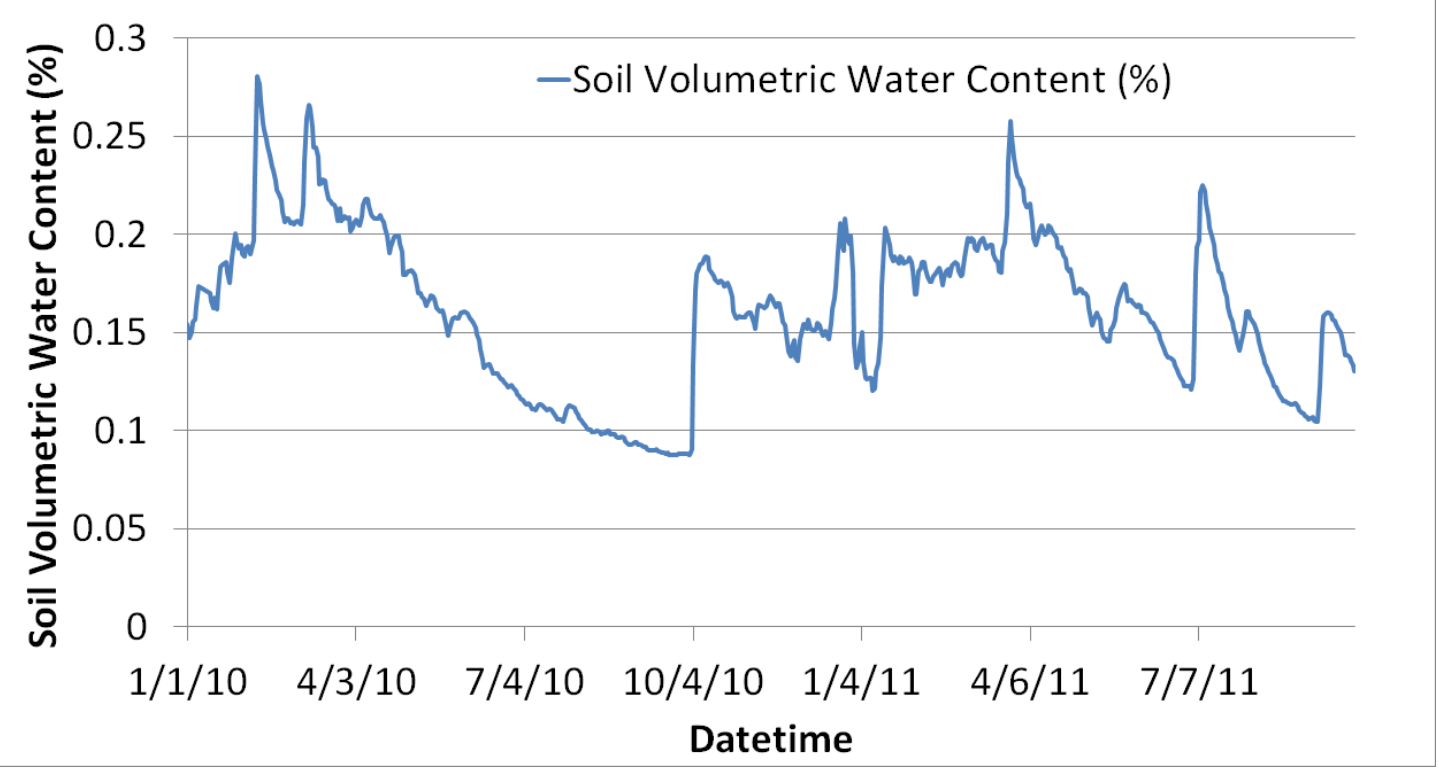

Figure 11. Soil volumetric water content trend for Station 401 for the period 1/1/2010 to 10/1/2011.

Wind is a major mechanism driving soil migration at TTR, and as such it is very important to monitor wind in conjunction with real-time particulate matter (PM) concentrations. This provides the ability to determine what conditions are conducive to transport. The wind roses in Figure 12 show wind trend at Stations 400, 401, and 402. Stations 400 and 401 contain the wind record between 1/1/2011 and 10/1/2011, whereas newly installed Station 402 contains the wind record between 6/1/2011 and 10/1/2011. There are two wind roses displayed for each station; the ones on the left show all winds and their contribution to the overall wind rose, and the others that show only the winds above 15 miles per hour. Generally speaking, winds above 15 mph result in elevated PM10 (particulate matter of aerodynamic radius of less than 10 micro meters) concentration in the air. PM10 is an indicator of small sized particles that are suspended in air and can be easily inhaled by the human respiratory system. The wind rose for Station 402 is included in order to illustrate different seasonal wind patterns. As can be seen from the wind roses on the bottom of Figure 12 , prevailing winds are from the south. This trend is even more pronounced in the figure that shows only the winds above $15 \mathrm{mph}$, where overwhelming majority of winds above 15 mph are coming from the south. This trend is also true for Stations 400 and 401 where there is a strong southerly wind component during summers. In addition, for Stations 400 and 401 there is strong component for the east and north-east during winter. 


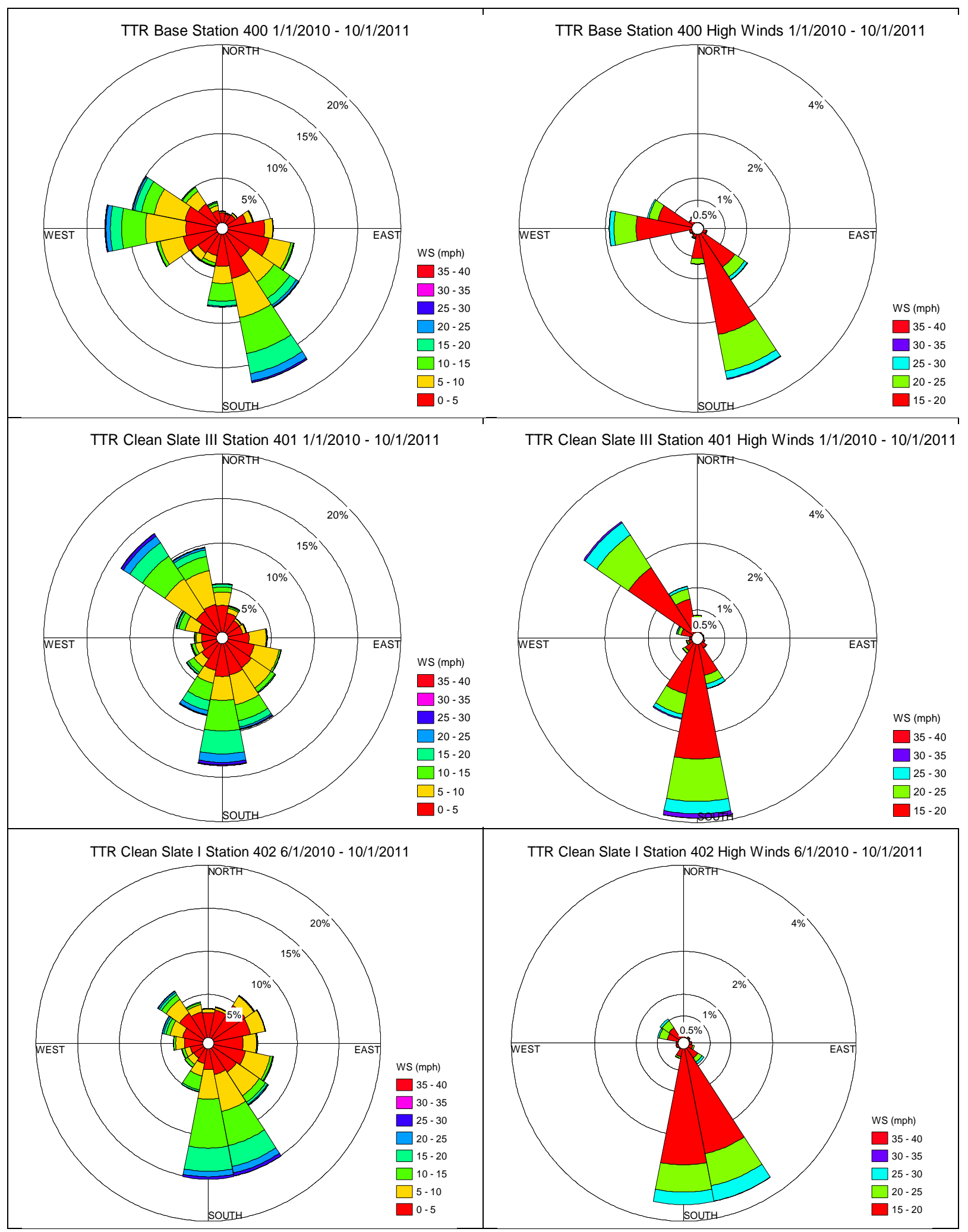

Figure 12. Wind roses for Station 400, 401, and 402 for period 1/1/2010 to 10/1/2011. 
Tables 1 and 2 summarize wind speeds by wind classes and corresponding PM10 concentrations for Stations 400 and 401. In Table 1 for Station 400 most of the time (92\%) average wind speed were below $15 \mathrm{mph}$ and corresponding PM10 concentrations were very low around $10 \mathrm{ug} / \mathrm{m} 3$. Although winds are above $15 \mathrm{mph}$ only $8 \%$ of the time, during those times there is a substantial increase in PM10 concentrations. Trends illustrated in Table 2 are very similar for Station 401, but measured winds are stronger somewhat more frequently (12\% of time above $15 \mathrm{mph}$ ), causing elevated PM10 concentrations more often.

Table 1. Wind and PM10 data summary for Station 400 for the period 1/1/2010 to 10/1/2011.

\begin{tabular}{ccccc}
\hline Wind Speed Class (mph) & Average Wind Speed (mph) & Duration $(\mathrm{h})$ & Fraction of Time & PM10(ug/m $\left.\mathrm{m}^{3}\right)$ \\
\hline $0-5$ & 3.0 & 7168.2 & 0.47 & 9.8 \\
$5-10$ & 7.1 & 4523.7 & 0.30 & 8.8 \\
$10-15$ & 12.2 & 2259.0 & 0.15 & 11.2 \\
$15-20$ & 17.1 & 974.0 & 0.06 & 17.5 \\
$20-25$ & 22.0 & 306.3 & 0.02 & 30.9 \\
$25-30$ & 26.6 & 63.7 & 0.00 & 64.4 \\
$30-35$ & 31.2 & 5.2 & 0.00 & 184.3 \\
$>35$ & 35.5 & 0.2 & 0.00 & N/A \\
\hline
\end{tabular}

Table 2. Wind and PM10 data summary for Station 401 for the period 1/1/2010 to 10/1/2011.

\begin{tabular}{ccccc}
\hline Wind Speed Class (mph) & Average Wind Speed $(\mathrm{mph})$ & Duration $(\mathrm{h})$ & Fraction of Time & PM10 $\left(\mathrm{ug} / \mathrm{m}^{3}\right)$ \\
\hline $0-5$ & 2.8 & 6249.5 & 0.42 & 7.1 \\
$5-10$ & 7.1 & 4534.3 & 0.30 & 6.3 \\
$10-15$ & 12.3 & 2338.7 & 0.16 & 6.2 \\
$15-20$ & 17.2 & 1218.8 & 0.08 & 8.3 \\
$20-25$ & 22.1 & 452.2 & 0.03 & 13.6 \\
$25-30$ & 26.8 & 136.0 & 0.01 & 22.9 \\
$30-35$ & 32.1 & 25.7 & 0.00 & 54.2 \\
$>35$ & 36.7 & 0.8 & 0.00 & 128.4 \\
\hline
\end{tabular}


Figures 13 and 14 display wind speed histograms for Stations 400 and 401 . These figures show relative frequencies of different wind speed magnitudes displayed in the wind roses. The data period covers 638 days and in that period for Station 401 there are only about 5 days (total time) of sustained winds between $25-30 \mathrm{mph}$, roughly 1 day of winds between 30-35 mph, and less than one hour of winds over $35 \mathrm{mph}$.

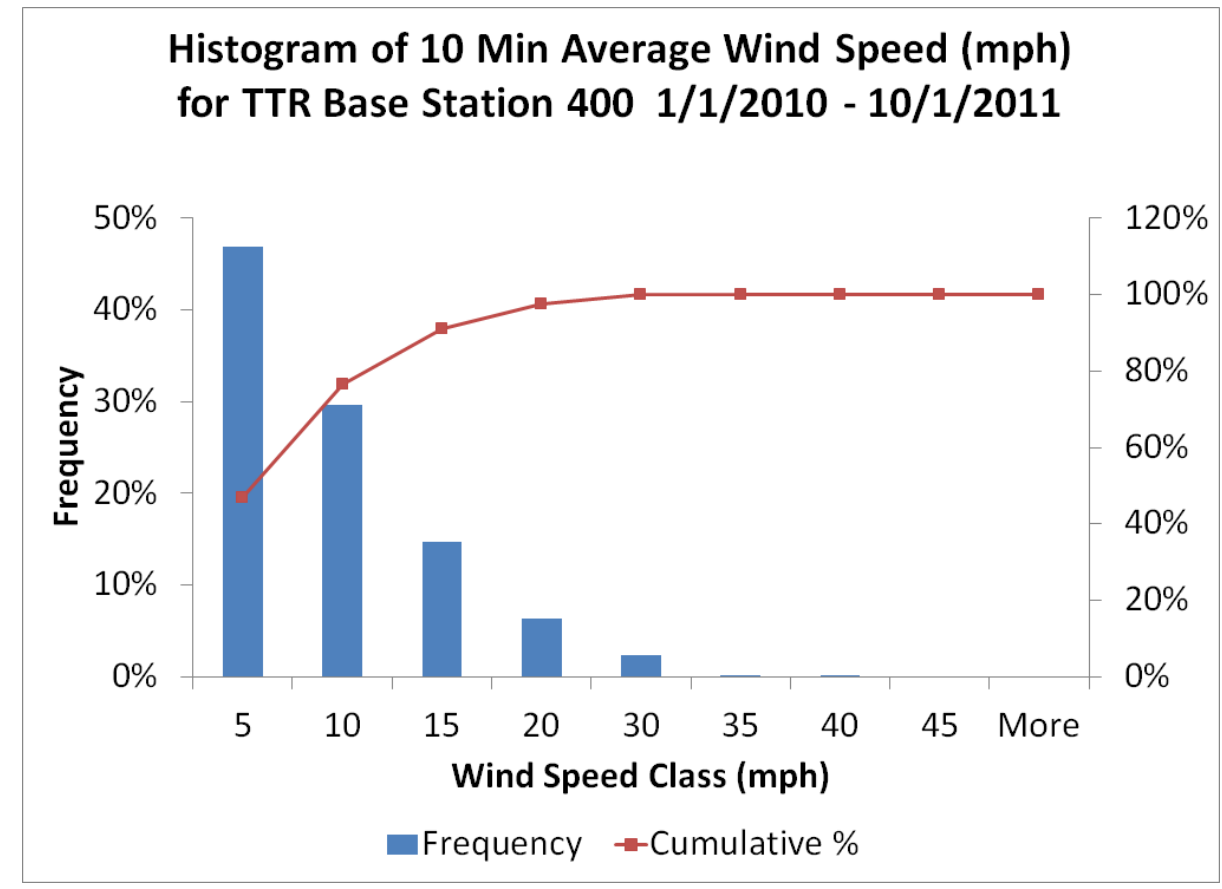

Figure 13. Wind speed histogram for Station 400 for the period 1/1/2010 to 10/1/2011.

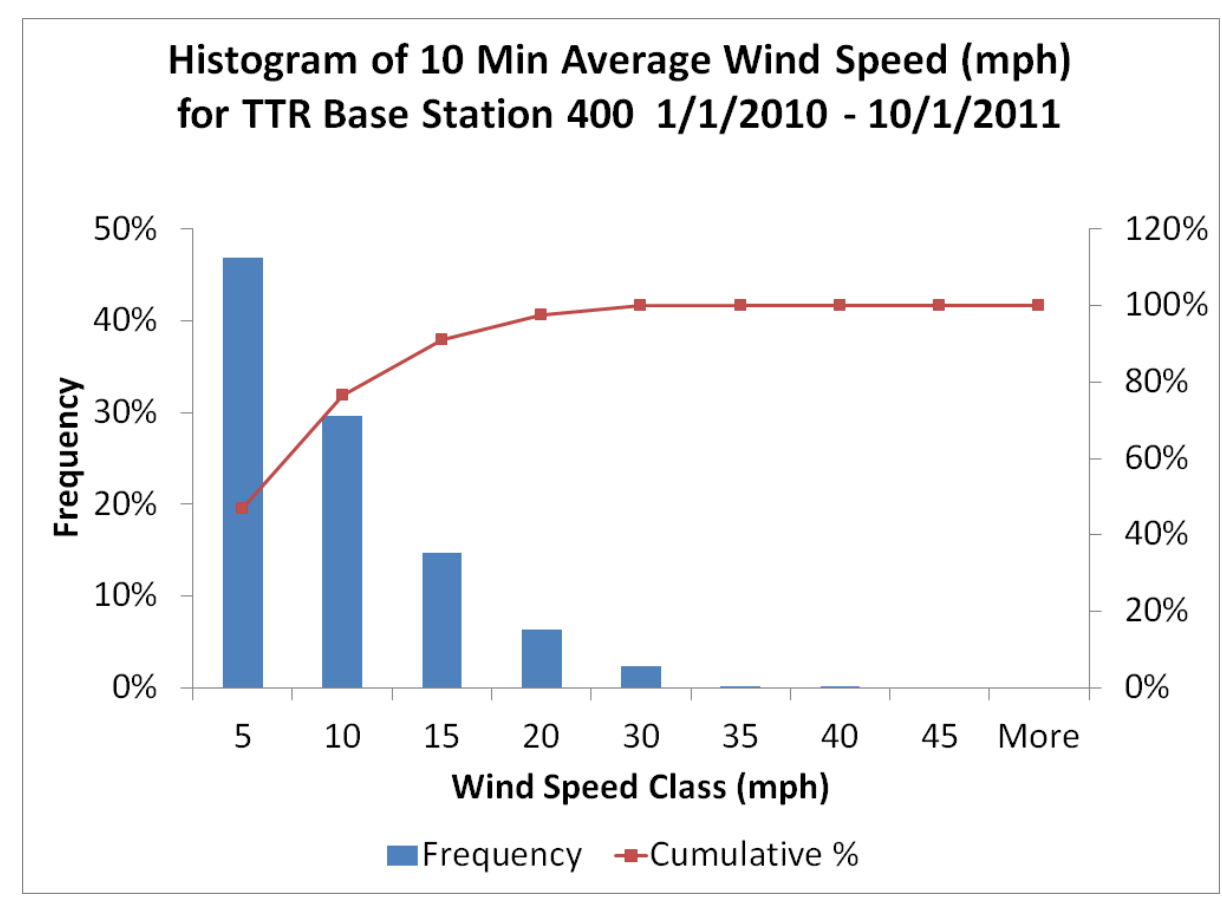

Figure 14. Wind speed histogram for Station 401 for the period 1/1/2010 to 10/1/2011. 
Figures 15 and 16 show the relationship between wind speed and air PM10 concentrations for Stations 400 and 401 respectively. The wind speed is grouped in different wind classes in $5 \mathrm{mph}$ increments as shown in Tables 1 and 2, with average PM10 concentration calculated for different wind classes. There is an exponential increase in PM10 with only linear increase in wind speed after $15 \mathrm{mph}$. It is important to remember that below 15 mph or around $90 \%$ of the time PM10 concentrations are very low and little or no soil migration occurs.

Figure 17 illustrates a high wind event that occurred at Station 401 between 4/28/2011 and 4/29/2011. Maximum hourly wind speed (red trace) reached almost $45 \mathrm{mph}$ and sustained average speed (blue trace) was around $30 \mathrm{mph}$. The average wind speed for most of the event was above 15 mph but PM10 concentration (purple trace) was below $25 \mathrm{ug} / \mathrm{m} 3$ most of the time. It was only during the highest recorded wind speeds that the PM10 concentration exceeded $200 \mathrm{ug} / \mathrm{m} 3$. This figure illustrates the impact of high wind speed on the PM10 concentration and soil migration. It is also important to note that this is a very non-linear process as shown in Figures 15 and 16, meaning that a relatively small increase in average wind speed from 25 to $30 \mathrm{mph}$ (20\% increase in wind speed) can result in an increase in PM10 from $20 \mathrm{ug} / \mathrm{m} 3$ to $200 \mathrm{ug} / \mathrm{m} 3$ (1000\% or 10-fold increase). Most of the transport events occur during short periods of time when winds are strong and exceed the saltation threshold. The saltation threshold is variable and depends on many other factors, including soil water volumetric content, crust strength, and vegetation cover. The saltation station installed in August of 2011 will help determine the flux of sand grain size particles in the vicinity of Clean Slate I and III ( Stations 401 and 402).

\section{Additional Tasks Completed}

DRI has assembled and lab and field-tested a portable air monitoring network to be used during activities at Soils sites on the TTR. The network is designed to monitor real time PM10 concentration and collect filter samples for chemical and radiological analysis. This monitoring network is made up of eight individual stations that are designed to run and collect continuous air samples for up to 48 hours on battery power. These stations can be installed at any location at TTR following a two day notice to DRI about the location and approximate time of when an activity is to take place. Each station is programmable to start running at specific time and for specific time duration up to 48 hours. Two different instruments are installed on each station. These instruments run at the same time and collect real time PM10 concentration with 1 minute time resolution and integrated 2 inch filter. This monitoring network was tested at TTR in August of 2011 during which DRI performed a full systems check and collected background data for the TTR training area. 


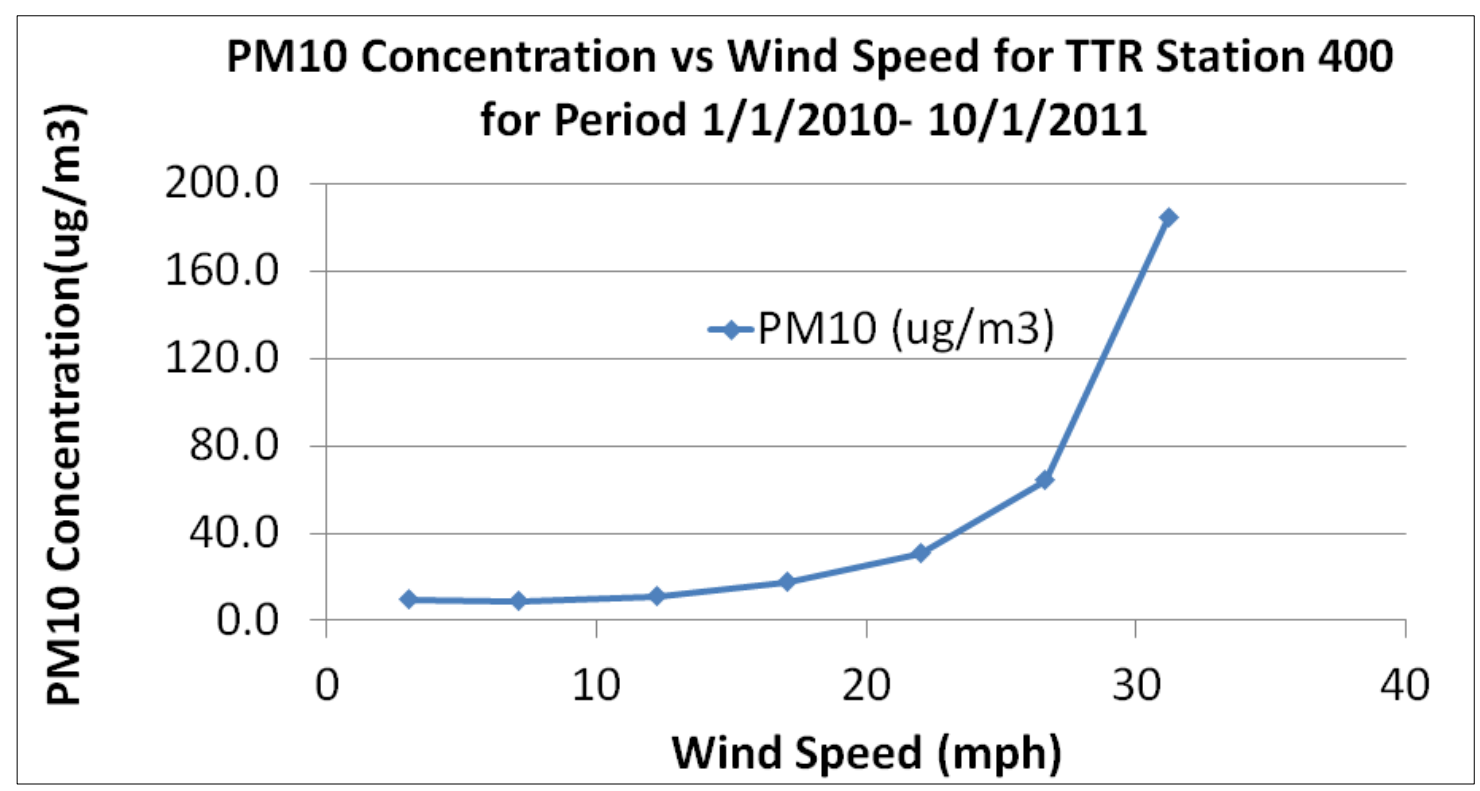

Figure 15. Wind speed and PM10 trends for Station 400 for the period 1/1/2010 to 10/1/2011.

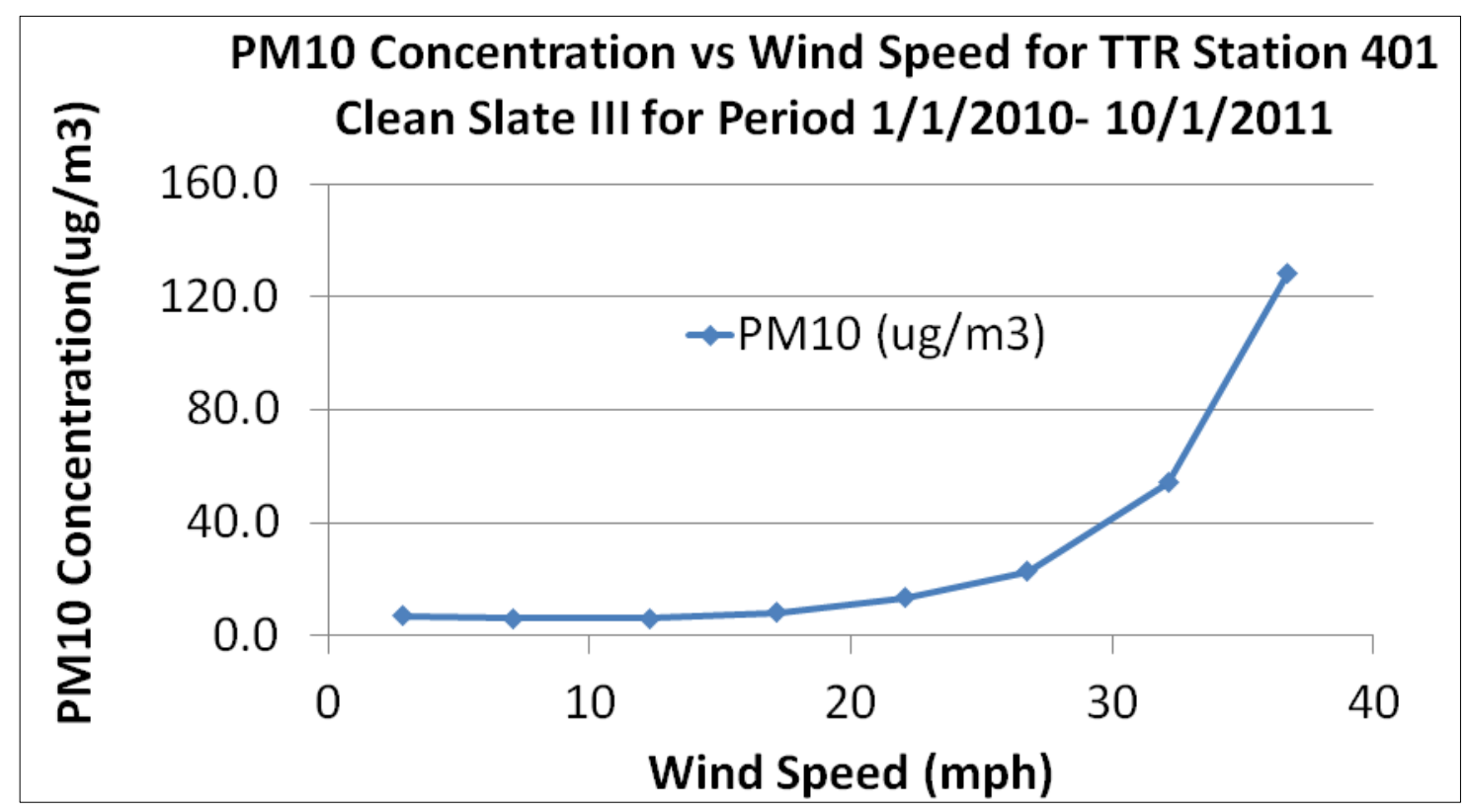

Figure 16. Wind speed and PM10 trend for Station 401 for the period 1/1/2010 to 10/1/2011. 


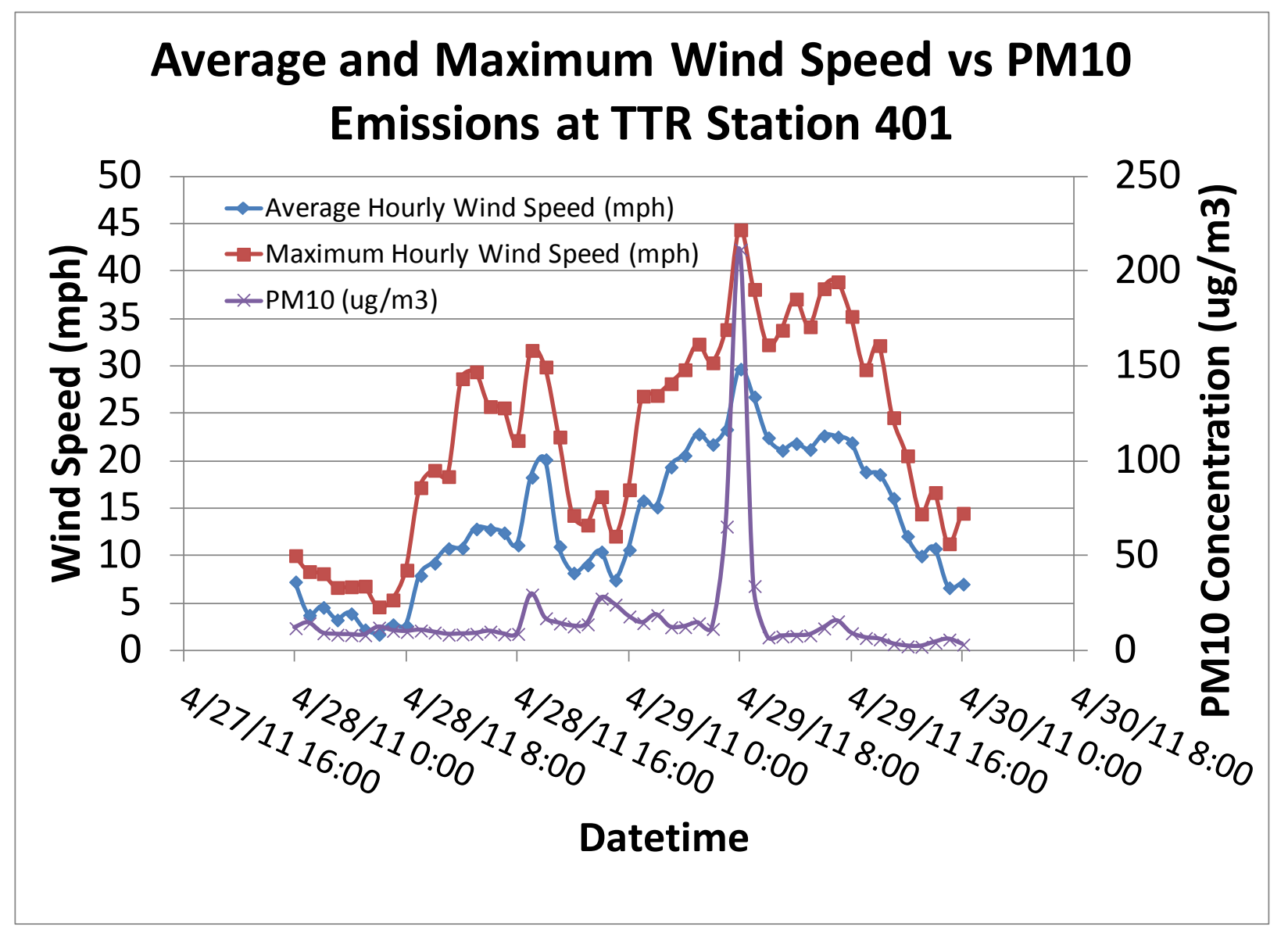

Figure 17. Sample high wind and high PM10 event for Station 401 from April, 2011.

\section{TTR Air Monitoring Network Database}

Data from the network at TTR are stored and managed via a database at the WRCC in Reno, Nevada. The database can be accessed via the web at http://www.wrcc.dri.edu/cgibin/rawMAIN.pl?nvcttr for Station 400 (ROC) data, http://www.wrcc.dri.edu/cgibin/rawMAIN.pl?nvctcs for Station 401 (CS III) data, : http://www.wrcc.dri.edu/cgibin/rawMAIN.pl?nvctc1 for Station 402 (CS I) data.. Available data includes:

- Solar radiation (station 400 only)

- Wind speed (minimum, maximum gust, and average) and direction

- Ambient air temperature (minimum, maximum, and average)

- Relative humidity (minimum, maximum, and average)

- Barometric pressure

- Precipitation (hourly and cumulative)

- Ambient gamma exposure rate (minimum, maximum, and average)

- Time domain reflectometer soil moisture probe @ 4 inch depth (minimum, maximum, and average) 
- Air particulate counts by size (0.3, 0.5, 0.7,1, 2, 2.5, and 10 micrometers) as a function of time

Batteries at Stations 401 and 402 are charged during the day from the solar panels, and are used to power the instruments at night so that data collection is continuous.

\section{FY 2012 Planned Activities}

DRI plans to conduct continued data collection and routine maintenance at the TTR stations. In addition, installation of field MiniVols ${ }^{\mathrm{TM}}$ may be accomplished, contingent on budget limitations.

\section{REFERENCES}

Engelbrecht, J.P, I.G. Kavouras, D. Campbell, S.A. Campbell, S. Kohl, D. Shafer, 2008. Yucca Mountain Environmental Monitoring System Initiative, Air Quality Scoping Study for Tonopah Airport, Nye County, Nevada, Letter report DOE/NV/26383LTR2008-04.

Hartwell, W.T., G. Nikolich, K. Giles, D. Shafer, L. Karr, T. Kluesner, 2010. Air Monitoring Network at Tonopah Test Range: Letter Report No. 2: Network Description and Capabilities. Prepared by the Center for Environmental Monitoring and Remediation, Desert Research Institute, for the US Department of Energy National Nuclear Security Administration, Nevada Site Office.

Sandia National Laboratories, 2011. 2010 Annual Site Environmental Report for Tonopah Test Range, Nevada and Kauai Test Facility, Hawaii, Sandia Report SAND2011-5616P, September 2011. 